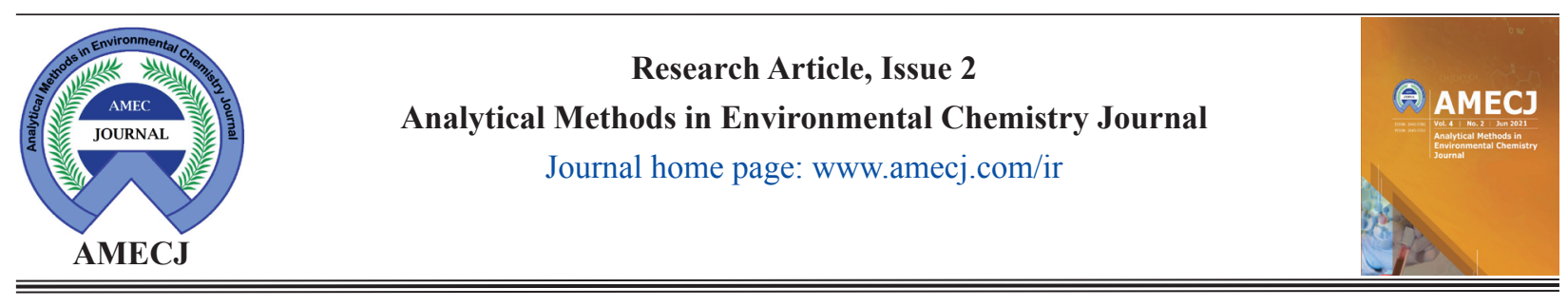

\title{
A rapid cadmium determination based on ion selective membrane potentiometric sensor by bis (salicylaldehydo) ethylenediimine as carrier
}

Mahdiyeh Ghazizadeh ${ }^{\mathrm{a}, *}$ and Hamideh Asadollahzadeh ${ }^{\mathrm{a}}$

a Department of Chemistry, Kerman branch, Islamic Azad University, Kerman, Iran, P. O. Box 7635131-167

\begin{tabular}{|c|c|}
\hline A RT I C L E I N F O : & A B S T R A C T \\
\hline Received 24 Feb 2021 & An ion selective potentiometric electrode (IPE) was prepared based \\
\hline Revised form 29 Apr 2021 & $\begin{array}{l}\text { on salen material (bis(salicylaidenydo)ethylenedimine) as a sultable } \\
\text { carrier for determination of cadmium ions. An acceptable response }\end{array}$ \\
\hline Accepted 17 May 2021 & for cadmium ions obtained over a linear range $8 \times 10^{-7}$ to $1.0 \times 10^{-2}$ \\
\hline Available online 27 Jun 2021 & $\begin{array}{l}\mathrm{M} \text { with a slope of } 29.8 \pm 0.8 \mathrm{mv} \text { per decade of activity and a detection } \\
\text { limit of } 3.2 \times 10^{-7} \mathrm{M} \text { for } \mathrm{Cd} \text { (II) ions in water and liquid samples. }\end{array}$ \\
\hline $\begin{array}{l}\text { Keywords: } \\
\text { Cadmium, } \\
\text { Ion selective electrode, } \\
\text { Membrane sensor, } \\
\text { Potentiometry, } \\
\text { Salen, } \\
\text { Water samples }\end{array}$ & $\begin{array}{l}\text { It has a response time less than } 10 \mathrm{~s} \text { and can be used for at least } \\
2.5 \text { months without any measurable divergence in potential. The } \\
\text { ion selective electrode can be used based on potential and potential } \\
\text { changes in the pH range } 3.5 \text { to } 6.5 \text {, so, the cadmium determination } \\
\text { was obtained at independent pH. Moreover, the selectivity of } \\
\text { proposed method in presence of interference ions was studied. The } \\
\text { results showed that the other cations do not interfere significantly in } \\
\text { response electrode at optimized pH. This electrode was successfully } \\
\text { used for the determination of cadmium ions in aqueous samples. The } \\
\text { validation was obtained based on ICP analyzer and certified reference } \\
\text { material in water samples (CRM, NIST). }\end{array}$ \\
\hline
\end{tabular}

\section{Introduction}

Due to recently reported by WHO, NIOSH and ACGIHA organizations, the heavy metals such as cadmium belong to harmful material for animals and humans. Heavy metals exist in different matrixes such as, food, tobacco smoke, air and water samples and have toxic effect in human cells. It may cause some serious diseases in humans such as renal failure, pancreatic/ liver cancers and accelerate tumor growth in human body [1] and some organs such as liver, kidneys or lungs may be hurt seriously [2]. So, the removal, separation and determination of heavy

\footnotetext{
*Corresponding Author: Mahdiyeh Ghazizadeh

Email: ghazizadeh1385@gmail.com

https://doi.org/10.24200/amecj.v4.i02.136
}

metals in blood serum, water and food samples is necessary. Cadmium has carcinogenesis effect in humans which was enter to human cells by the inhalation, food, waters [3]. Cadmium concentrations in natural waters are less than $1 \mu \mathrm{g} \mathrm{L}^{-1}$. The tissues kidneys and livers can be concentrated cadmium. Levels in fruit and vegetables are below $10-1000 \mu \mathrm{g} \mathrm{kg}^{-1}$ in liver and in kidney. Cadmium determined by atomic absorption spectroscopy (ETAAS, FAAS) using aspiration water samples into a flame or injection to graphite tube of furnace spectrometric technique (ET-AAS) [4,5]. The LOD is $10 \mu \mathrm{gL}^{-1}$ with the GBC spectrometer of F-AAS and 0.1 $\mu \mathrm{g} \mathrm{L}^{-1}$ with ET-AAS was obtained. Cadmium can be determined by chemical vapor generation atomic fluorescence spectrometry(CVG-AFS) 
and carbon paste ion selective electrode(CP-IS) $[6,7]$.The potentiometric method and chemical sensors are the reproducible and rapid methods for cadmium determination in liquid phases. In recent years, the design of chemical sensors as interested method based on highly selective carriers and ion-selective electrodes (ISEs) was reported by researchers for determination of various ionic species such as $\mathrm{Pb}, \mathrm{Cd}, \mathrm{V}$ and Hg. The potentiometric sensors act based on ion-selective electrodes (ISEs) and the electrochemical response is usually controlled by one ionic species presented in the solution. Numerous applications of these potentiometric selective electrodes have been reported. Biochemical applications and environmental applications are two important examples for this propose [8]. The Schiff base ligands were easily prepared from the condensation of a ketone or an aldehyde compounds with an amine groups. Ionophores include antibiotics and use to shift ruminal fermentation patterns. Many ionophores are lipid-soluble entities that transport ions across the cell membrane. They are suitable ionophore to form effective ionselective electrodes, because of affinity toward metal ions $[9,10]$. The Schiff bases are ligands with mixed $\mathrm{O}, \mathrm{N}$-donor atoms which bonds to some transition metal ions, such as $\mathrm{Mn}(\mathrm{II})$, $\mathrm{Fe}(\mathrm{III}), \mathrm{Cu}(\mathrm{II}), \mathrm{Pb}(\mathrm{II}), \mathrm{Cd}(\mathrm{II})$. The Schiff base ligands are so important for their various applications in dye and plastic industries, liquid crystal technology, biochemistry and physiology [11]. They are also use in development of photonic devices and have potential applications such as metallomesogens [12]. However, despite extensive applications of these ligands and many reports on synthesis and characterization of the Schiff base ligands and their complexes, there are a few reports on their ion-selective studies [13-16]. Moreover, it seems that Schiff base ligands are suitable ionophores for preparation ion selective electrodes and determination of many metal ions [17, 18]. Among Schiff bases, salens are tetradentate ligands that derived from salicylaldehyde and could be formed to stable complexes with transition metal ions. For these reasons, we used the salen compound as carrier in ion selective membrane for determination of $\mathrm{Cd}$ (II).

\section{Experimental}

\subsection{Materials}

Ethanol, methanol, acetone, sodium tetraphenylborate (NaTPB), dibutyl phthalate (DBP) and tetrahydrofuran with high purify (99\%) were purchased from Merck chemical company. High relative molecular weight polyvinyl chloride (PVC) was purchased from sigma chemical company. Reagent grade nitrate salts of the used cations (all from Merck) were of the highest purity available and were used without any further purification. Aqueous solutions were prepared with doubly distilled water. Sodium hydroxide $(0.1 \mathrm{M})$ and nitric acid $(0.1 \mathrm{M})$ were used for $\mathrm{pH}$ control. The target Schiff base was synthesized from salicylaldehyde and ethylene diamine and purified as described elsewhere.

\subsection{Instruments}

Control of $\mathrm{pH}$ was achieved by a digital $\mathrm{pH}$ meter (inoLab 7110, Germany). The reference calomel electrode (RCE) has reaction between elemental mercury and mercury(I) chloride. However, the calomel electrode has a reputation of being more robust. The liquid phase in contact with the $\mathrm{Hg} / \mathrm{HgCl}$ in a saturated solution of $\mathrm{KCl}$. The electrode is normally linked via a porous frit to the solution as a salt bridge. Finally, all of potentiometric measurements were made with a $\mathrm{pH} / \mathrm{mV}$ meter (Zag Chimi, Iran) using calomel electrode (Azar electrode, Iran). The electrode of system to act as a reference against which potential measurements can be made and potentiometric methods was obtained based on measurements of the potential of electrochemical cells in the absence of appreciable currents and basic components such as reference electrode (gives reference for potential measurement), the indicator electrode and salt bridge and potential measuring device were used as Schema 1. 


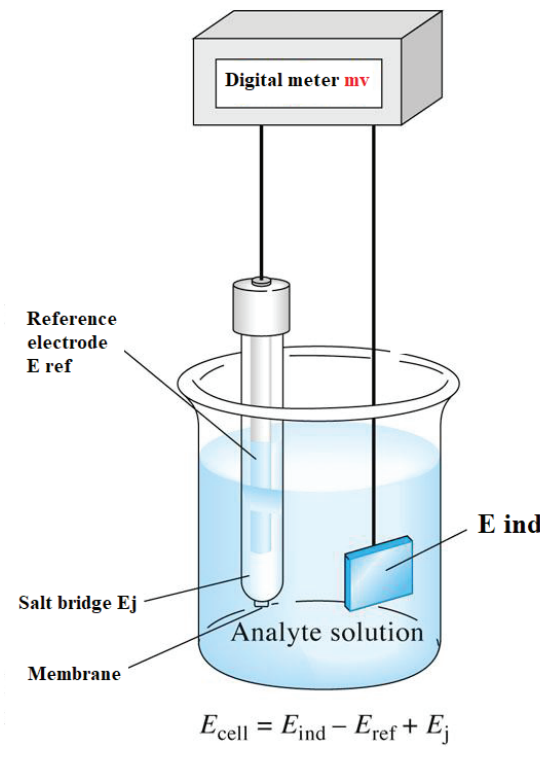

reference electrode $\mid$ salt bridge $\mid$ analyte solution $\mid$ indicator electrode

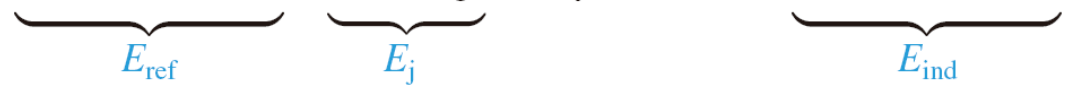

Schema 1. The potentiometric methods based on measurements of the potential of electrochemical cells

\subsection{Electrode preparation}

Preparation of the PVC membrane achieved by mixing thoroughly $61 \mathrm{mg}$ of powdered PVC, $134.6 \mathrm{mg}$ of plasticizer DBP, $2 \mathrm{mg}$ of NaTBP and $6.12 \mathrm{mg}$ of ionophore (Fig. 1) in $10 \mathrm{~mL}$ of THF. The mixture was transferred into a glass dish of $2 \mathrm{~cm}$ diameter. The solvent was evaporated in room temperature during 5-6 hours until an oily concentrated mixture was left. A Pyrex tube was dipped into the oily mixture for a few seconds, so that a non-transparent film was formed. Then the tube was pulled out from the mixture and kept at room temperature for 48 hours to produce a dry membrane. After that the tube was filled with an internal $1.0 \times 10^{-3} \mathrm{M}$ solution of $\mathrm{Cd}\left(\mathrm{NO}_{3}\right)_{2} \cdot 4 \mathrm{H}_{2} \mathrm{O}$. The electrode was finally conditioned for 24 $\mathrm{h}$ by soaking in a solution of $1.0 \times 10^{-2} \mathrm{M}$ $\mathrm{Cd}\left(\mathrm{NO}_{3}\right)_{2} \cdot 4 \mathrm{H}_{2} \mathrm{O}$.

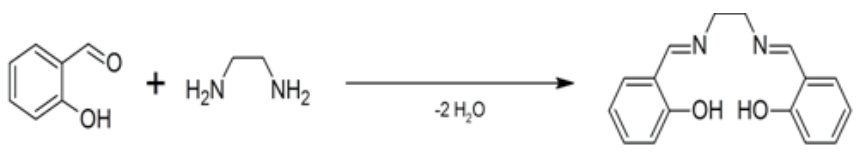<smiles>C1=C2CCC3=Cc4ccccc4OC23Oc2ccccc21</smiles><smiles>CN=Cc1ccccc1O</smiles><smiles>CN=Cc1ccccc1O</smiles>

Fig. 1. The synthesis and structure of salen as ionophore and complexation with cadmium 


\subsection{Emf measurements}

All emf measurements were done with the following assembly:

$\mathrm{Hg} / \mathrm{Hg}_{2} \mathrm{Cl}_{2}$ (sat'd), $\mathrm{KCl}$ (sat'd) | internal solution, $\mathrm{Cd}\left(\mathrm{NO}_{3}\right)_{2} \cdot 4 \mathrm{H}_{2} \mathrm{O}\left(1.0 \times 10^{-3} \mathrm{M}\right) \mid \mathrm{PVC}$ membrane | sample solution $\mid \mathrm{Hg} / \mathrm{Hg}_{2} \mathrm{Cl}_{2}$ (sat'd), $\mathrm{KCl}$ (sat'd)

All emf measurements were carried out in a 50 $\mathrm{mL}$ of double walled glass cell with a constant magnetic stirring of the test solution. Activities were calculated according to Debye-Huckel procedure about solutions of electrolytes and plasmas. Debye-Huckel procedure provides a starting point for modern treatments of non-ideality of electrolyte solutions based on 2-dimensional section of electrolyte solution. The ions have as spheres with unit negative and positive charges. The EMF of the cell for varying the concentrations of one participating electrolyte $(\mathrm{HCl})$ will be measured. This measurement verifies the Debye-Huckel limiting Law and to determine the mean activity coefficient of the electrolyte.

\section{Results and Discussion}

\subsection{Potentiometric response of the prepared sensor}

At first, membrane electrodes were prepared based on PVC by using of salen as ionophore. Then potentiometric responses of sensors to the different metal ions were investigated under the same conditions. It is obvious that the best response to the metal ions belongs to cadmium ion (Fig. 2).

\subsection{Effect of the membrane composition}

It is obvious that the electrode response depends on the nature and the amount of the electrode's components. The data clearly show that the electrode response does not improve by increasing of the ionophore's amount. This divergence in electrode response in higher concentration of the ionophore caused the less selectivity and enhanced interference of the lipophilic counter ions of the test solution as assumed in the phase boundary potential model of carrier based ISEs. Plasticizer also plays an important role in electrode responses and influences the detection limits [19, 20], the sensitivity and selectivity [21] of the electrodes. Moreover, the nature of the additive may have significant effect on the sensitivity and selectivity [22-24]. Thus, cadmium selective electrodes prepared with different amounts of ionophore and the aspects of membrane preparation based on salen for $\mathrm{Cd}^{2+}$ were optimized and the results are reported in Table 1. It indicates that membrane no. 9 with an optimized composition of $66 \%$ DBP, $30 \%$

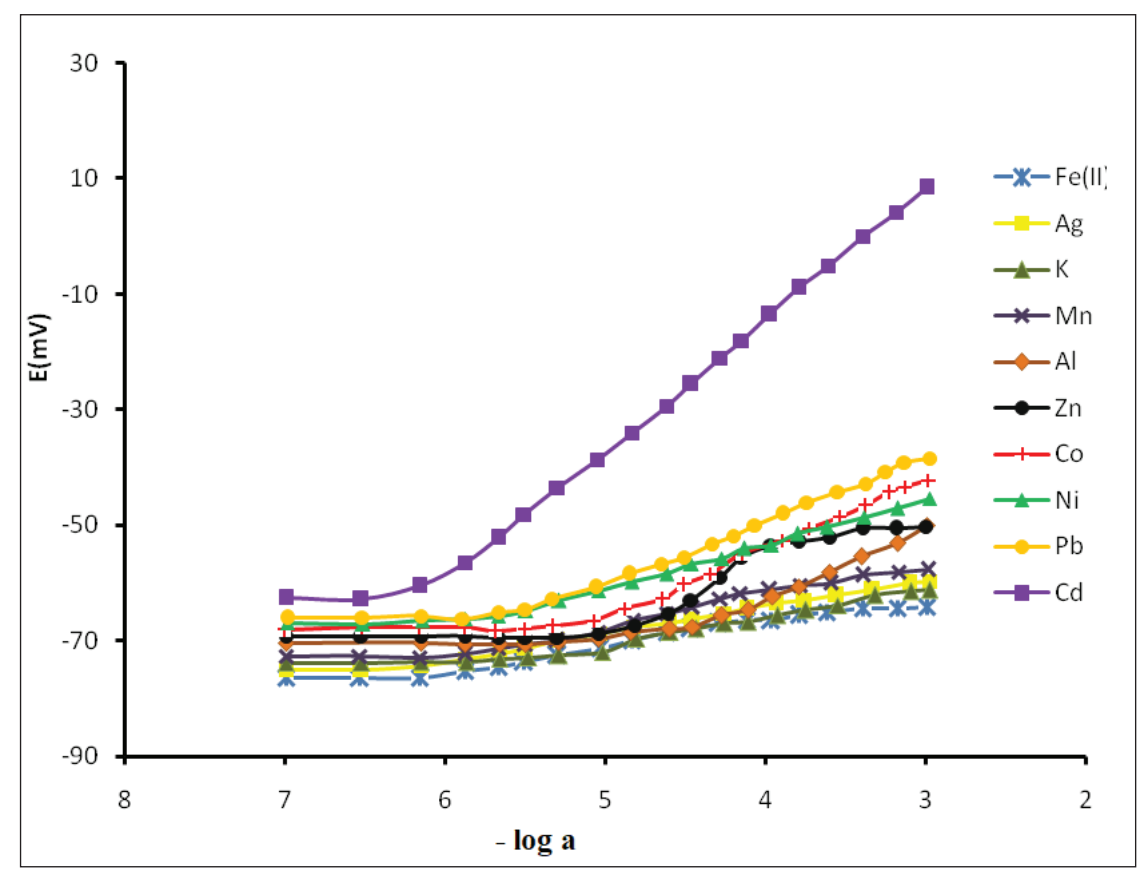

Fig 2. The responses of different ion selective electrodes 
PVC, 3\% ionophore and 1\% NaTBP due to the best sensitivity. It has a Nernstian slope of $29.8 \pm 0.8$ $\mathrm{mV}$ decade ${ }^{-1}$ activity of $\mathrm{Cd}^{2+}$ ions with an extensive dynamic range.

\subsection{Effect of $p H$}

The effect of $\mathrm{pH}$ on the responses of cadmium-selective electrode was investigated by adjusting $\mathrm{pH}$ over a range of 2.0-9.0. It was achieved by using small drops of nitric acid $(0.1 \mathrm{M})$ or sodium hydroxide $(0.1 \mathrm{M})$ and $1.0 \times 10^{-3} \mathrm{M} \mathrm{Cd}^{2+}$ solution. The Figure 3 showed that potential is constant over a $\mathrm{pH}$ range of 3.5-6.5. Thus $\mathrm{pH}$ was adjusted at 5 for all experiments. The observed decreasing of electrode potential at higher $\mathrm{pH}$ values could be due to the interference of hydroxide ion. Acidic solutions can also cause the less potential at low $\mathrm{pH}$ because of protonating of ionophore and interference of $\mathrm{H}^{+}$ions.

Table 1. Composition and optimization of the membranes ingredients.

\begin{tabular}{|c|c|c|c|c|c|}
\hline Numbers & ionophore(\%) & NaTBP)(\%) & DBP(\%) & PVC(\%) & 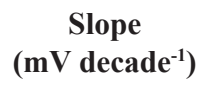 \\
\hline 1 & 4.5 & 2.5 & 63 & 30 & $24.6 \pm 0.9$ \\
\hline 2 & 5 & 2 & 63 & 30 & $21.8 \pm 0.4$ \\
\hline 3 & 3.5 & 2.5 & 64 & 30 & $22.3 \pm 0.6$ \\
\hline 4 & 3 & 0 & 67 & 30 & $27.7 \pm 0.5$ \\
\hline 5 & 0 & 5 & 65 & 30 & $18.8 \pm 0.3$ \\
\hline 6 & 4 & 1 & 65 & 30 & $25.7 \pm 0.7$ \\
\hline 7 & 2 & 3 & 65 & 30 & $23.8 \pm 0.9$ \\
\hline 8 & 5.5 & 2.5 & 62 & 30 & $20.2 \pm 0.3$ \\
\hline 9 & 3 & 1 & 66 & 30 & $29.8 \pm 0.8$ \\
\hline 10 & 7 & 3 & 60 & 30 & $21.6 \pm 0.4$ \\
\hline
\end{tabular}

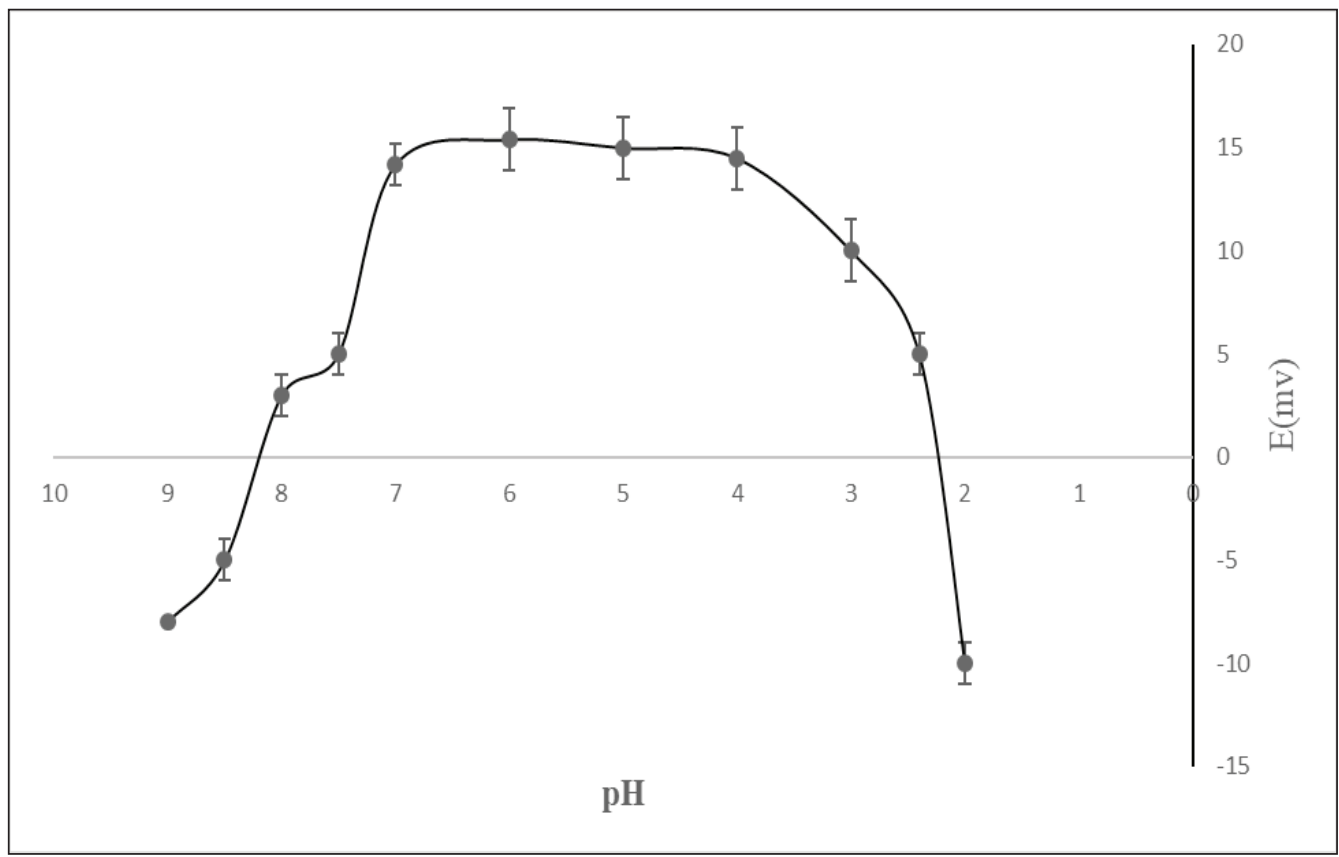

Fig. 3. Influence of $\mathrm{pH}$ on the potential response of cadmium selective electrode $\left(1.0 \times 10^{-3} \mathrm{M} \mathrm{Cd}^{2+}\right)$ 


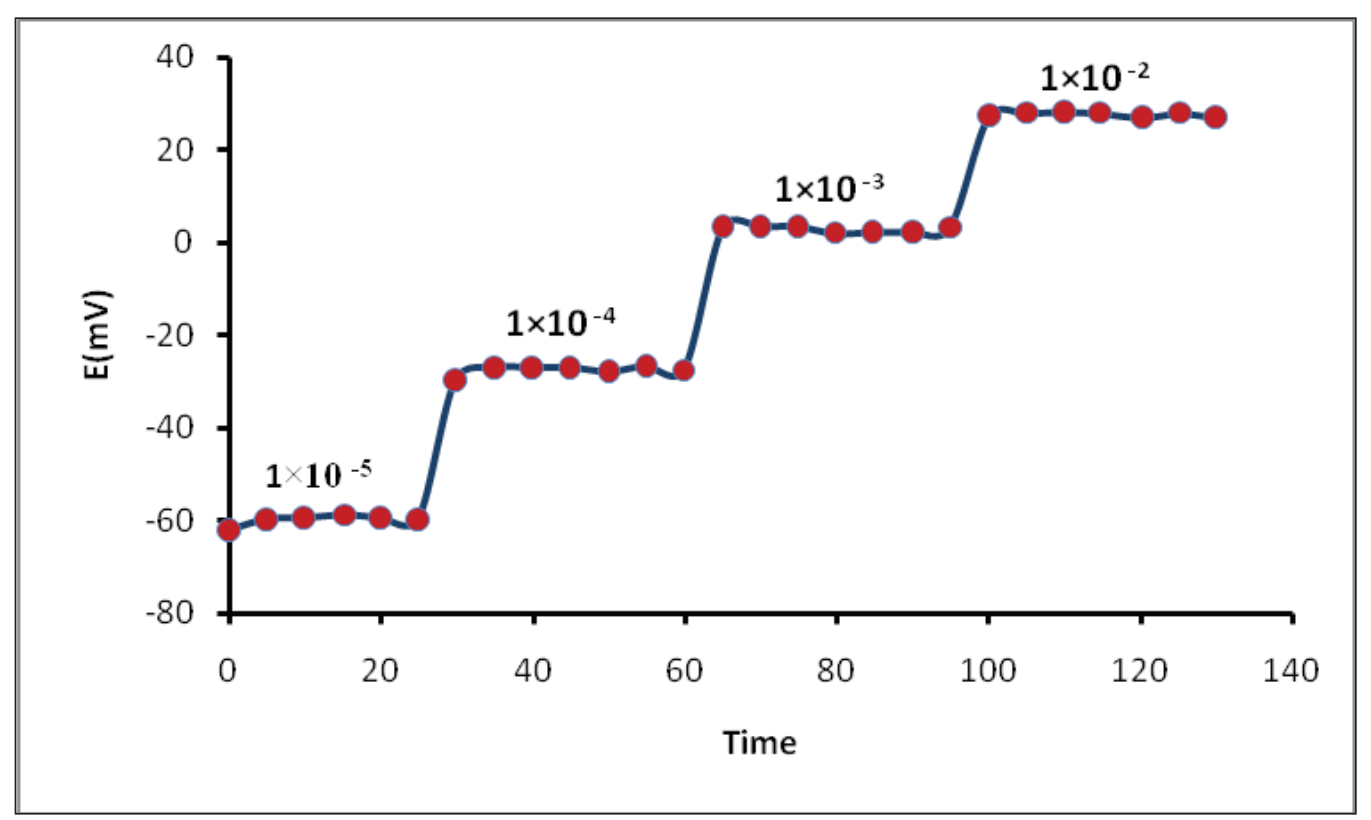

Fig. 4. Response time of cadmium selective electrode

\subsection{Response time}

An important factor for all ionic selective electrodes is dynamic response time. In this research, the practical response time was measured by changing the $\mathrm{Cd}^{2+}$ concentration from $1.0 \times 10^{-2}$ to $1.0 \times 10^{-5} \mathrm{M}$ in solution. The response time was about $10 \mathrm{~s}$ did not change by varying $\mathrm{Cd}^{2+}$ concentration (Fig. 4). This is most probably result in the fast exchanging of complexation-decomplexation of $\mathrm{Cd}^{2+}$ ion with the ionophore (salen) at the test solutionmembrane interface.

\subsection{Effect of internal solution}

The effect of internal solution concentration on the potentiometric responses of cadmium ion selective electrode was investigated. There was no considerable change in the potentiometric responses by using different concentrations of internal solution in the range of $1.0 \times 10^{-4}$ to $1.0 \times$ $10^{-1} \mathrm{M}$. Therefore $1.0 \times 10^{-3} \mathrm{M}$ was chosen for the concentration of internal solution.

\subsection{Effect of non-aqueous solutions}

The potentiometric responses of cadmium-selective electrode were studied in non-aqueous solutions by using several mixtures such as water/methanol,

Table 2. Effect of non-aqueous solutions on the slope and linear range of the prepared electrode

\begin{tabular}{ccc}
\hline Non-aqueous solution (V/V\%) & Linear range $(\mathbf{M})$ & Slope $\left(\mathbf{m V ~ d e c a d e} \mathbf{~}^{-1}\right)$ \\
\hline 0 & $1.0 \times 10^{-2}-3.8 \times 10^{-6}$ & $29.1 \pm 0.4$ \\
\hline Ethanol 10\% & $1.0 \times 10^{-2}-3.0 \times 10^{-6}$ & $29.0 \pm 0.5$ \\
Ethanol 15\% & $1.0 \times 10^{-2}-3.0 \times 10^{-6}$ & $28.9 \pm 0.5$ \\
Ethanol 20\% & $1.0 \times 10^{-2}-1.1 \times 10^{-6}$ & $26.3 \pm 0.6$ \\
Ethanol 25\% & $1.0 \times 10^{-3}-1.3 \times 10^{-5}$ & $24.5 \pm 0.7$ \\
\hline Methanol 10\% & $1.0 \times 10^{-2}-3.0 \times 10^{-6}$ & $29.1 \pm 0.6$ \\
Methanol 15\% & $1.0 \times 10^{-2}-3.0 \times 10^{-6}$ & $29.0 \pm 0.5$ \\
Methanol 20\% & $1.0 \times 10^{-2}-4.1 \times 10^{-6}$ & $27.1 \pm 0.6$ \\
Methanol 25\% & $1.0 \times 10^{-2}-4.1 \times 10^{-6}$ & $25.4 \pm 0.5$ \\
\hline Acetone 10\% & $1.0 \times 10^{-2}-3.0 \times 10^{-6}$ & $29.1 \pm 0.6$ \\
Acetone 15\% & $1.0 \times 10^{-2}-3.0 \times 10^{-6}$ & $28.5 \pm 0.7$ \\
Acetone 20\% & $1.0 \times 10^{-2}-2.1 \times 10^{-6}$ & $24.1 \pm 0.7$ \\
Acetone 25\% & $1.0 \times 10^{-2}-1.3 \times 10^{-5}$ & $19.0 \pm 0.8$ \\
\hline
\end{tabular}


water/ethanol and water/acetone with 10, 15, 20 and 25 volume percent of non-aqueous part (Table 2). The results indicated a slope decreasing when the volume percent of non-aqueous solution was more than $15 \%$.

\subsection{Potentiometric selectivity}

The effect of interfering ions on the potentiometric behavior of Cadmium ion selective electrode, known as potentiometric selectivity coefficients, was studied. The results showed the other ions do not interfere in potentiometric responses of the prepared electrode based on salen as ionophore (Table 3). Therefore, Cd-selective electrode has high selectivity for cadmium ions.

\subsection{Calibration curve and statistical data}

Optimized equilibrium time for membrane electrode is $24 \mathrm{~h}$. After that the potentiometric responses of electrode was defined according to IUPAC. The potential response of the electrode to different concentration of $\mathrm{Cd}$ (II) ion in the range of $8 \times 10^{-7}$ to $1.0 \times 10^{-2} \mathrm{M}$ at $\mathrm{pH}=5$ (Fig. 5) indicates a linear response and the slope of calibration curve was 29.8 $\pm 0.8 \mathrm{mV} /$ decade of concentration of $\mathrm{Cd}^{2+}$ at room temperature. The standard deviation of 5 replicate measurements is $\pm 0.5 \mathrm{mV}$. The detection limit as determined from the crossing of the two extrapolated parts of the calibration curve was $3.2 \times 10^{-7} \mathrm{M}$. The PVC membrane electrode could be applied for at least 2.5 months without any measurable change.

Table 3. Potentiometric selectivity coefficients of various interfering cations.

\begin{tabular}{|c|c|}
\hline Cation & $\mathbf{K}_{\mathbf{C d}(\mathbf{I I}), \mathbf{J}}$ \\
\hline $\mathrm{Ni}^{2+}$ & $2.4 \times 10^{-3}$ \\
$\mathrm{Co}^{2+}$ & $2.5 \times 10^{-3}$ \\
$\mathrm{~Pb}^{2+}$ & $6.8 \times 10^{-3}$ \\
$\mathrm{Cr}^{3+}$ & $1.1 \times 10^{-3}$ \\
$\mathrm{Al}^{3+}$ & $3.3 \times 10^{-3}$ \\
$\mathrm{Na}^{+}$ & $3.1 \times 10^{-3}$ \\
$\mathrm{~K}^{+}$ & $1.8 \times 10^{-3}$ \\
\hline
\end{tabular}

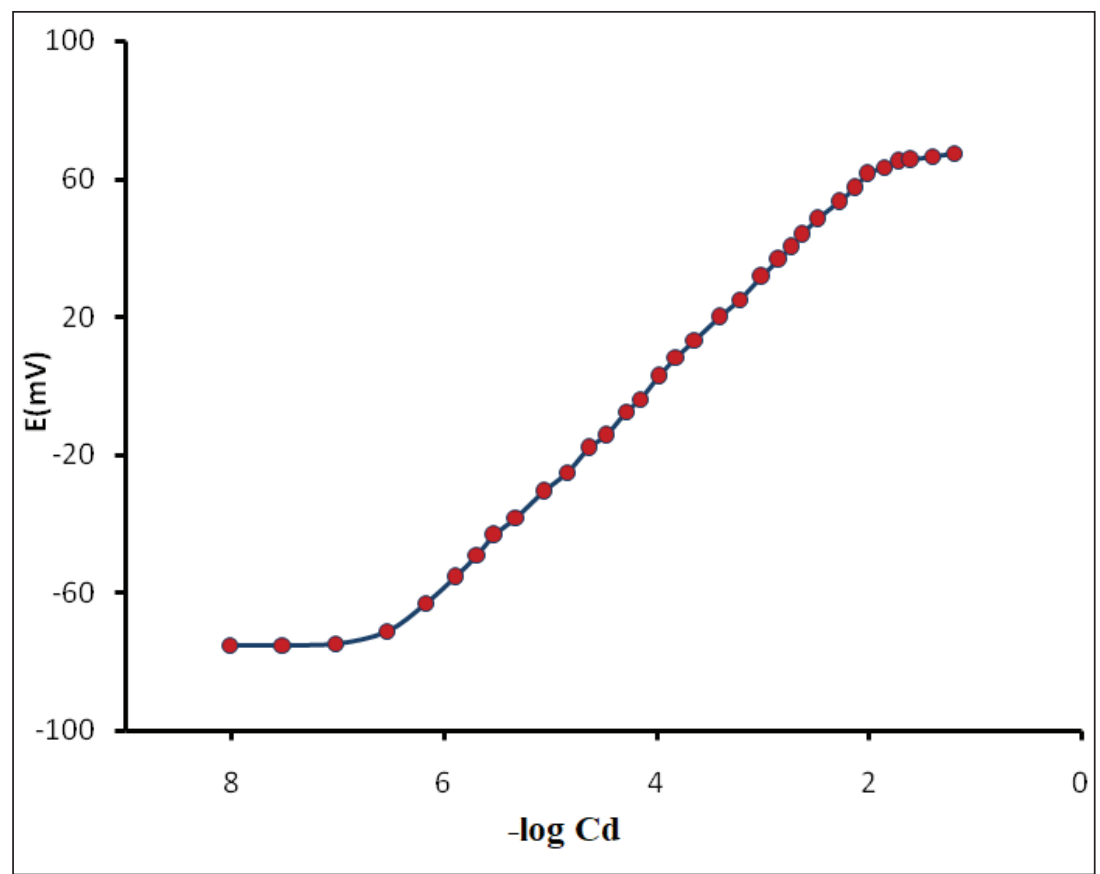

Fig. 5. Potentiometric response of the $\mathrm{Cd}^{2+}$ ion selective electrode to cadmium concentration using the optimized membrane electrode. 
Table 4. Determination of $\mathrm{Cd}^{2+}$ by the new ion selective electrode and recovery.

\begin{tabular}{|c|c|c|c|c|c|c|c|c|c|}
\hline \multirow{2}{*}{ Sample } & \multicolumn{3}{|c|}{$\mathrm{Cd}^{2+} \operatorname{added}\left(\mathrm{mol} \mathrm{L}^{-1}\right)$} & \multicolumn{3}{|c|}{$\mathrm{Cd}^{2+}$ found $^{\mathrm{a}}\left(\mathrm{mol} \mathrm{L}^{-1}\right)$} & \multicolumn{3}{|c|}{ Recovery (\%) } \\
\hline & $\begin{array}{l}\text { Sample } \\
\text { I }\end{array}$ & $\begin{array}{c}\text { Sample } \\
\text { II }\end{array}$ & $\begin{array}{c}\text { Sample } \\
\text { III }\end{array}$ & $\begin{array}{c}\text { Sample } \\
\text { I }\end{array}$ & $\begin{array}{c}\text { Sample } \\
\text { II }\end{array}$ & $\begin{array}{c}\text { Sample } \\
\text { III }\end{array}$ & $\begin{array}{c}\text { Sample } \\
\text { I }\end{array}$ & $\begin{array}{c}\text { Sample } \\
\text { II }\end{array}$ & $\begin{array}{c}\text { Sample } \\
\text { III }\end{array}$ \\
\hline $\begin{array}{l}\text { Ground } \\
\text { water }\end{array}$ & --- & $5.5 \times 10^{-5}$ & $1.0 \times 10^{-4}$ & $<\mathrm{LOD}$ & $(5.7 \pm 0.05) \times 10^{-5}$ & $(1.04 \pm 0.03) \times 10^{-5}$ & --- & 103 & 104 \\
\hline $\begin{array}{l}\text { River } \\
\text { water }\end{array}$ & --- & $5.5 \times 10^{-5}$ & $1.0 \times 10^{-4}$ & $<\mathrm{LOD}$ & $(5.6 \pm 0.06) \times 10^{-5}$ & $(9.7 \pm 0.08) \times 10^{-5}$ & --- & 101 & 97 \\
\hline
\end{tabular}

${ }^{a}$ Mean value \pm standard deviation (three determination)

\subsection{Analytical applications at real sample}

The prepared cadmium selective ion electrode based on salen was successfully applied for determination of cadmium ions concentration in the samples of water. The results are shown in Table 4.

\section{Conclusions}

Rapid response, low detection limit and high selectivity, make ion selective electrodes suitable for measuring the concentration of metal ions. Salen was easily synthesized and used as ionophore in preparing an ion selective electrode for direct determination of cadmium. The prepared electrode showed high selectivity and low detection limit. This electrode also applied successfully for Cd ions determination in the samples of water.

\section{Acknowledgement}

The authors are gratefull to Islamic Azad University, Kerman Branch, for financial assistance of this work.

\section{References}

[1] F. Zheng, B. Hu, Thermo-responsive polymer coated fiber-in-tube capillary microextraction and its application to on-line determination of $\mathrm{Co}, \mathrm{Ni}$ and $\mathrm{Cd}$ by inductively coupled plasma mass spectrometry (ICP-MS), Talanta, 85 (2011) 1166-1173.
[2] P. Wu, Ch. Li, J. Chen, Ch. Zheng, X. Hou, Determination of cadmium in biological samples: An update from 2006 to 2011, Appl. Spectrosc. Rev., 47 (2012) 327-370.

[3] G. Adani, T. Filippini, Dietary intake of acrylamide and risk of breast, endometrial and ovarian cancers: A systematic review and doseresponse meta-analysis, Cancer Epidemiol. Biomarkers Prev., 29 (2020) 1095-1106.

[4] L.A. Meira, D.F. de Souza, Application of constrained mixture design and Doehlert matrix in the optimization of dispersive liquid-liquid microextraction assisted by ultrasound for preconcentration and determination of cadmium in sediment and water samples by FAAS, Microchem. J., 130 (2017) 56-63.

[5] M. Naghizadeh, M.A. Taher, M. Behzadi, F.H. Moghaddam, Preparation a novel magnetic natural nano zeolite for preconcentration of cadmium and its determination by ETAAS, Environ. Nanotechnol. Monit. Manag., 8 (2017) 261-267.

[6] J. Zhang, J. Fang, X. Duan, Determination of cadmium in water samples by fast pyrolysis-chemical vapor generation atomic fluorescence spectrometry, Spectrochim. Acta Part B , 122 (2016) 52-55. 
[7] M.R. Ganjali, H. Khoshsafar, F. Faridbod, A. Shirzadmehr, M. Javanbakht, P. Norouzi, Room temperature ionic liquids (RTILs) and multiwalled carbon nanotubes (MWCNTs) as modifiers for improvement of carbon paste ion selective electrode response; a comparison study with PVC membrane, Electroanal. Int. J., 21(2009) 2175-98.

[8] R. Yan, Sh. Qiu, L. Tong, Y. Qian, Review of progresses on clinical applications of ion selective electrodes for electrolytic ion tests: from conventional ISEs to graphene-based ISEs, Chem. Speciat. Bioavailab., 28 (2016) 72-77.

[9] W.A. Zoubi, N.A. Mohanna, Membrane sensors based on Schiff bases as chelating ionophores - A review, Spectrochim. Acta A Mol. Biomol. Spectrosc., 132 (2014) 854-870.

[10] C. Mohan, K. Sharma, S. Chandra, Cd(II) ionselective electrode based on 2-acetylthiophene semicarbazone in polymeric membrane, Anal. Bioanal. Electrochem., 9 (2017) 35-46.

[11] A. Xavier1, N. Srividhya, Synthesis and study of Schiff base ligands, IOSR-J. Appl. Chem., 7 (2014) 6-15.

[12] C. Cretu, L. Caseh, B.J. Tang, V. Badea, E.I. Szerb, G. Mehi, S. Shova, O. Cosistor, Mononuclear $\mathrm{Cu}(\mathrm{II})$ complexes of novel salicylidene Schiff bases: synthesis and mesogenic properties, Liq. Cryst., 42 (2015) 1139-1147.

[13] A. Vijayalakshmi, J. Thamarai Selvi, Calcium ion selective electrode based on Schiff base as an electro active material-Its preparation and analytical application, Int. J. Curr. Res., 5 (2013) 2176-2178.

[14] Y.H. Ma, R. Yuan, Y.Q. Chai, X. Wu, W. Zhou, X.L. Liu, F. Deng, New Ni(II) ion-selective electrode based on the N-S Schiff base ligand as neutral carrier in PVC matrix, Anal. Lett., 42 (2009) 2411-2429.

[15] S. Suman, R. Sighn, Thiophene-based Schiff base ligand as ionophore for $\mathrm{Ni}(\mathrm{II})$-selective polyvinyl chloride membrane electrode, J. Polym. Eng., 40 (2020) 481-485.
[16] T. Tamoradi, H. Goudarziafshar, S. Rashki, F. Katouzian, F. Chalabian, Synthesis of new Schiff base ligand and its complexes in the presence of some transition metal ion and evaluation of their antibacterial properties, Med. Lab. Sci., 11 (2017) 5-10.

[17] K.R. Bandi, A.K. Singh, A. Upadhyay, Biologically active Schiff bases as potentiometric sensor for the selective determination of $\mathrm{Nd}^{3+}$ ion, Electrochim. Acta, 105 (2013) 654-664.

[18] A.Q. Alorabi, M. Abdelbaset, S.A. Zabin, Colorimetric detection of multiple metal ions using Schiff base 1-(2-Thiophenylimino)4-(N-dimethyl)benzene, Chemosensors, 8 (2020) 1-10.

[19] H.M. Abu Shawish, N. Abu Ghalwa, A.R.AlDalou, F.R. Zaggout, S.M. Saadeh, A.A. Abou Assi, Effect of plasticizers and ionexchangers on the detection limit of tramadolPVC membrane electrodes, Eurasian J. Anal. Chem., 6 (2011) 70-83.

[20] P. Adhikari, L. Alderson, F. Bender, A.J. Ricco, F. Josse, Investigation of polymerplasticizer blends as SH-SAW sensor coatings for detection of benzene in water with high sensitivity and long-term stability, ACS Sens., 2 (2017) 157-164.

[21] C. Carey, Plasticizer effects in the PVC membrane of the dibasic phosphate selective electrode, Chemosensors, 3 (2015) 284-294.

[22] A.R. Fakhari, M. Shamsipour, Kh. Ghanbari, $\mathrm{Zn}$ (II)-selective membrane electrode based on tetra(2-aminophenyl) porphyrin, Anal. Chim. Acta, 460 (2002) 177-183.

[23] A.R. Fakhari, M. Alaghemand, M. Shamsipur, Iron(III)-selectivemembranepotentiometricsensor basedon5,10,15,20-tetrakis(pentafluorophenyl)21H,23H-porphyrin, Anal. Lett., 34 (2001) 1097-1106.

[24] A.R. Fakhari, T. Ahmad Raji, H. Naeimi, Copper-selective PVC membrane electrodes based on salens as carriers, Sens. Actuators B Chem., 104 (2005) 317-323. 